This is an Accepted Manuscript of an article published by the American Society of Civil Engineers in the Journal of Management Engineering. May 2010. This material may be downloaded for personal use only. Any other use requires prior permission of the American Society of Civil Engineers. This material may be found at https://doi.org/10.1061/(ASCE)ME.1943-5479.0000031

A FINAL Manuscript submitted to the

Journal of Management in Engineering, ASCE

\title{
Application of Equity Sensitivity Theory to Problem-solving Approaches in Construction Dispute Negotiation
}

(The audience of the paper shall include both researchers and practitioners)

\section{Manuscript No.: MEENG-119R1}

Tak Wing Yiu, ${ }^{1, *}$ Chung Wai Keung ${ }^{2}$ and Kit Ling Wong ${ }^{3}$

*Corresponding Author

Dr. Tak Wing Yiu

Department of Building and Construction

City University of Hong Kong

83 Tat Chee Avenue

Hong Kong

Tel: (852) 34426779

Tel: (852) 27887612

E-mail: bctwyiu@cityu.edu.hk

April 2010 
${ }^{1}$ Lecturer,

Department of Building and Construction,

City University of Hong Kong

83 Tat Chee Avenue, Hong Kong

${ }^{2}$ Instructor,

Department of Building and Construction,

City University of Hong Kong

83 Tat Chee Avenue, Hong Kong

${ }^{3}$ Project student,

Department of Building and Construction,

City University of Hong Kong

83 Tat Chee Avenue, Hong Kong 


\title{
Application of Equity Sensitivity Theory to Problem-solving Approaches in Construction Dispute Negotiation
}

\author{
Tak Wing Yiu, Chung Wai Keung and Kit Ling Wong \\ Department of Building and Construction \\ City University of Hong Kong
}

\begin{abstract}
This study applies equity sensitivity theory to investigate how the sensitivity of negotiators to perceived equity or inequity varies with their perception of the adoption of problem-solving approaches (PSAs) in negotiation in the construction industry. Drawing upon this theory, we identify three classes of negotiators: Benevolents (known as "givers"), Equity Sensitives and Entitleds (known as "takers"). Our results suggest that most of the negotiators in our sample are Entitleds. The study also provides statistical evidence that the perception of the adoption of PSAs appears to be associated with the degree of equity sensitivity of negotiators. For instance, Benevolents demonstrate a significantly stronger preference for the adoption of PSAs and are thus able to obtain a higher level of negotiation satisfaction compared to the other types of negotiators. These findings are particularly relevant to the corporate managers of construction organizations, who may want to consider the inherent equity sensitivity traits of their negotiators before sending them to the negotiating table.
\end{abstract}




\section{Introduction}

Negotiation is a basic business survival skill. This skill, however, is seldom learned by practitioners in the construction industry. Negotiation in this industry involves a significant level of interaction among negotiators, who include project managers, engineers and surveyors and typically are employed by clients or contractors. The traditional adversarial relationship between clients and contractors has long been identified as a major source of claims and disputes (Cheung et al. 2003; Al-Momani 2000; Cheung and Liu 1995; Jannadia et al. 2000; Yiu and Cheung 2006). Industrial reviews (Egan 1998; CIRC 2001; Latham 1994) and research studies (Cheung and Yiu 2006; Cheung et al. 2002; Zack 1995; Pinnell 1999; Steen and MacPherson 2000) report that the construction business is dispute prone and characterized by an antagonistic and non-cooperative culture. It is suggested that contracting parties adopt problem-solving approaches (PSAs) to resolve disputes as they arise (Egan 1998; CIRC 2001; Latham 1994). PSAs involve negotiating behavior and focus on solving mutual problems in a way that is accommodating, honest and unbiased. Negotiators who adopt such approaches are cooperative, integrative and information exchange oriented (Graham 1986). The adoption of a PSA is regarded as the most effective way to resolve organizational conflict (Nickerson and Zenger 2004; Rahim 2002; Ghauri 1986; Calantone et al. 1998) and build long-term relationships (Ganesan 1994). Such approaches provide a strong impetus to understand cultural differences (Eliashberg et al. 1995; Dabholkar et al. 1994) and simulate actual negotiation behavior (Graham 1985; Graham and Andrews 1987). PSAs have been widely 
investigated in the field of business negotiation (e.g., Graham 1985, 1986; Adler and Graham 1989; Mintu-Wimsatt 2005). That research generally suggests that negotiators should adopt a PSA as their first move, as the first move sets the tone for the entire negotiating process. In addition, as bargaining interaction is often characterized by reciprocal exchanges (Goering 1997; Putman and Jones 1982; Alexander et al. 1991), integrative (or distributive) messages tend to be matched by integrative (or distributive) responses (Mintu-Wimsatt 2005). Studies show that when one party adopts a PSA, his or her negotiating partner is likely to adopt one as well (Graham 1986; Calantone et al. 1998). Negotiators in the construction industry often face tough negotiation processes that involve the diverse interests of the various contracting parties, including clients, contractors and sub-contractors. The typically adversarial and non-cooperative culture of this industry may pose a particular difficulty for negotiators who would like to adopt PSAs. This study addresses the way in which they may be encouraged to do so. We first conceptualize the negotiator's sensitivity to perceived equity or inequity (hereafter, equity sensitivity) by applying equity sensitivity theory at the individual level. Three classes of negotiators (hereafter, equity sensitivity groups) are identified according to their different responses to perceived equity or inequity. Next, the differences in the perception of the adoption of PSAs and level of negotiation satisfaction among the three equity sensitivity groups are investigated. As negotiation in the construction industry often involves the resolution of disputes or claims, a better understanding of those differences will be beneficial to negotiators who would like to adopt PSAs. The findings of this study will also help the 
corporate managers of construction organizations to recognize and understand the importance of the equity sensitivity of their negotiators.

\section{Theoretical Background}

Equity sensitivity theory, which was proposed by Adams $(1963,1965)$ and refined later by Huseman et al. (1987), among others, suggests that individuals evaluate their relationships with others by assessing the ratio of the inputs and outcomes of those relationships against the input/outcome of a comparison other (Miles et al. 1994; Foote and Harmon 2006; Adam 1963, 1965). However, perceptions of what is fair can vary, as some individuals may view certain elements as inputs, whereas others may view them as outcomes (Tornow 1971). In this connection, Huseman et al. (1987) reconceptualized equity sensitivity theory to provide a conceptual framework, which is based on individual psychological differences, for the prediction of the reactions of individuals to perceived inequity (King et al. 1993; Mintu-Wimsatt 2005) and their preferences for and satisfaction with outcomes (King et al. 1993; Miles et al. 1989; Patrick and Jackson 1991). More recently, equity sensitivity theory has been applied by researchers in a number of fields including cultural studies (Wheeler 2002; Mintu-Wimsatt 2004; Allen et al. 2005), business (Shore 2004; Ruyter and Wetzels 2000), psychology (Foote and Harmon 2006) and organizational behavior (Blakely et al. 2005; Bing and Burroughs 2001; Scott and Colquitt 2007). Three equity sensitivity groups, Benevolents, Equity Sensitives and Entitleds, have been hypothesized based on their input/outcome ratios (Huseman et al. 1987; Mintu-Wimsatt 2005). Benevolents are individuals who prefer their 
input/outcome ratio to be less than that of the comparison other (Huseman et al. 1987), and are more satisfied with negotiation outcomes than are Equity Sensitives or Entitleds (Huseman et al. 1985). This classification system has been used by negotiation researchers to distinguish three types of negotiators: benevolent, equity-sensitive and entitled (Mintu-Wimsatt 2005; King et al. 1993). At the negotiating table, benevolent negotiators think more about giving than receiving (Rychlak 1973), make valuable contributions to the relationship and are prepared to cooperate (Mosak 1959). They are the "givers" at the negotiating table, those who are willing to provide inputs to their negotiating partners. These negotiators tend to express a high level of satisfaction relative to others when their input/outcome ratios are lower than those of their negotiating partners and are distressed when these ratios are equal or their own is higher (Mintu-Wimsatt 2005; Sauley and Bedeian 2000; McLoughlin and Carr 1997; Miles et al. 1989; King et al. 1993; Huseman et al. 1987). Equity Sensitives, in contrast, adhere more closely to the original equity theory predictions (Adams, 1963, 1965). They subscribe to the norm of equity and experience distress or even guilt when they are either over- or under-rewarded. Equity-sensitive negotiators are most content when their input/outcome ratios are equal to those of their negotiating partners (Mintu-Wimsatt 2005; Sauley and Bedeian 2000; Huseman et al. 1987), and will attempt to bring these ratios back into balance if either party is over- or under-rewarded (Allen and White 2002). Finally, Entitleds are those individuals who prefer that their input/outcome ratio exceed that of the comparison other (Huseman et al. 1987). They are intolerant of being under-rewarded but more tolerant than 
either Equity Sensitives or Benevolents of being over-rewarded (King et al. 1993). Entitled negotiators are known as the "takers" at the negotiating table. They are most satisfied when they receive more outcomes than inputs and prefer getting to giving (Mintu-Wimsatt 2005; Allen and White 2002; Sauley and Bedeian 2000; King et al. 1993; Huseman et al. 1987; Miles et al. 1989). Based on the inherent traits of these three classes of negotiators, we hypothesize that their perceptions of the adoption of PSAs and levels of negotiation satisfaction may be different. Benevolent negotiators are predicted to take the initiative during the course of negotiations to work together with their negotiating partners to share information about needs and preferences. If their partners reciprocate this behavior, then they will obtain satisfaction. This supposition is supported by the finding of Calantone et al. (1998) and Campbell et al. (1998) that negotiators often express a high level of satisfaction when a PSA is used by both parties at the negotiation table. Calantone et al. (1998) and Graham (1986) identify four types of satisfaction: (1) satisfaction with negotiation outcomes, (2) satisfaction relative to pre-negotiation expectations, (3) satisfaction with the level of organizational profit and (4) satisfaction with negotiating performance. These provide the basis for evaluating the success or failure of negotiations and are the factors that lead to desired negotiation outcomes (Calantone et al. 1998).

Based on the foregoing discussion, we put forward the following hypotheses. 
Hypothesis 2: If negotiators belong to different equity sensitivity groups, then their perceptions of the adoption of an accommodating PSA will differ.

Hypothesis 3: If negotiators belong to different equity sensitivity groups, then their perceptions of the adoption of an honest PSA will differ.

Hypothesis 4: If negotiators belong to different equity sensitivity groups, then their perceptions of the adoption of an unbiased PSA will differ.

Hypothesis 5: If negotiators belong to different equity sensitivity groups, then their levels of satisfaction with negotiation outcomes will differ.

Hypothesis 6: If negotiators belong to different equity sensitivity groups, then their levels of satisfaction with negotiation outcomes relative to pre-negotiation expectations will differ.

Hypothesis 7: If negotiators belong to different equity sensitivity groups, then their levels of satisfaction with the level of organizational profit will differ.

Hypothesis 8: If negotiators belong to different equity sensitivity groups, then their levels of satisfaction with negotiating performance will differ.

\section{Method}

\section{Data Collection}

The primary objective of this study was to investigate how the perception of the adoption of PSAs and the level of negotiation satisfaction varies among benevolent, equity-sensitive and entitled negotiators. To achieve this objective, a questionnaire was designed to collect data from target respondents in Hong Kong. These were professionals in construction organizations, 
namely, project managers, surveyors, architects and engineers, whose responsibilities include negotiating claims and disputes for their organizations. The target respondents were selected from construction companies that were registered in the Builder Directory and from the Web pages of professional institutes. Those who agreed to participate in the study were sent a questionnaire survey by post, fax or e-mail, according to their preference. This questionnaire survey was developed in line with the following measures.

\section{Measures of Equity Sensitivity}

The Equity Sensitivity Instrument (ESI) is a well-established measure of equity sensitivity that was developed by Huseman et al. $(1985,1987)$, and is used to identify differences in the way individuals view inequitable situations (Foote and Harmon 2006). This five-item forced-distribution scale gauges the preferences of respondents for inputs versus outcomes during negotiation. Each item comprises two statements: an entitled and a benevolent response (Sauley and Bedeian 2000). Respondents are asked to indicate their preference by distributing 10 points between the two statements. Foote and Harmon (2006) pointed out four attributes of the ESI: (1) it demonstrates a high degree of internal reliability, (2) it appears to be unidimensional, (3) all of its items that are related to the input/outcome exchange are derived from equity theory and (4) it may be more representative of the general public as it was developed using a non-student sample. The ESI has been widely used in previous equity sensitivity studies (Mintu-Wimsatt 2003; Allen and White 2002; Wheeler 2002; Kickul and Lester 2001; Miles et al. 1989; King et al. 1993; Miles et al. 1994; O’Neill and Mone 1998; 
Patrick and Jackson 1991). For these reasons, we chose the ESI to measure equity sensitivity, although we modified its content to suit the construction context. A sample of the modified ESI is given in Appendix A, and the ESI results are covered in the Findings and Discussion section.

\section{PSAs and Negotiation Satisfaction}

Different PSAs and negotiation satisfaction were measured using the problem-solving approach dimensions (hereafter, PSA dimensions) developed by Graham (1986), which have been used extensively to investigate negotiation behavior (Graham et al. 1994; Adler and Graham 1989; Mintu-Wimsatt 2004, 2005). They comprise two sets of questions. In the first set, the perception of respondents of solving mutual problems is measured by the question: "Do you feel that you are more interested in solving mutual problems or are you more self-interested?" Respondents are asked to rate the degree of their self-interest/interest in solving mutual problems on a Likert scale that ranges from 1 "completely self-interested" to 7 "completely interested in solving mutual problems." Three other major PSAs, the accommodating, honest and unbiased approaches, are rated using 7-point, self-reported, itemized-category scales with opposing adjectives as anchors (Graham et al. 1994). These scales range from 1 "exploitative" to 7 "accommodating," from 1 "deceptive" to 7 "honest" and from 1 "biased" to 7 "unbiased," respectively. Negotiation satisfaction is measured by four questions: (a) "How satisfied were you with the negotiation outcome(s)?" (b) "How satisfied were you with the negotiation outcome(s) relative to your pre-negotiation 
expectations?" (c) "How satisfied were you with your organizational profit level?" and (d) "How satisfied were you with your performance during the negotiation process?" These questions are evaluated using a 7-point Likert scale that ranges from 1 "low degree of satisfaction" to 7 "high degree of satisfaction." The content of the original PSA dimensions was slightly modified to suit the construction context. For example, as construction negotiators represent the interests of profit-making organizations (Loosemore 1999), the question "How satisfied were you with your individual profit level" was modified to read "How satisfied were you with your organizational profit level?" A sample of the PSA dimensions appears in Appendix B.

To test the hypotheses, one-way analysis of variance (ANOVA) was performed to determine whether there were any significant differences in perception of PSA adoption and level of negotiation satisfaction among the three classes of negotiators. ANOVA is a type of statistical analysis that is used to evaluate the equality of means, such as mean differences, of a single intervally-scaled outcome across two or more groups (Thompson 2006). The significant ANOVA results were then followed up using Duncan's Multiple Range Test (hereafter, Duncan's test), a widely used procedure for determining the source of any significant differences (Miles et al. 1994; Montgomery 1997; King et al. 1993).

\section{Findings and Discussion}

A total of 165 questionnaires were distributed to the target respondents, 90 of whom returned completed questionnaires, giving a response rate of $54.50 \%$. The composition by organization 
type of the respondents, $72 \%$ of whom had more than five years of experience in construction negotiation, is presented in Table 1.

$<$ Table 1 here >

\section{ESI Scores}

The ESI scores are the sum of the points allotted to the two benevolence statements (King et al. 1993), and range from 6 to 47 (mean $=23.83, \mathrm{SD}=7.28)$ out of a possible range of 0 to 50 . To divide the sample into the three equity sensitivity groups, the sample-specific breakpoints used by Huseman et al. (1985), Miles et al. $(1989,1994)$ and King et al. (1993) were adopted, as the unique characteristics of any particular sample may influence ESI responses (King et al. 1993). These breakpoints were approximately \pm half a standard deviation from the mean of the entire sample (King et al. 1993), and the resulting three categories are presented in Table 2 . Respondents with a score of 20 or less were classified as Entitleds ( $n=29$, mean $=16.03$, SD $=3.59)$; those with scores between 21 and 27 as Equity Sensitives $(n=35$, mean $=23.94, \mathrm{SD}$ $=2.10)$; and those with scores of 28 or greater as Benevolents $(\mathrm{n}=26$, mean $=32.38, \mathrm{SD}=$ 4.63). The distribution of these three classes of negotiators by organization, including private developer, government agency, consultancy firm or contractor, is shown in Table 3.

$<$ Table 2 here >

$<$ Table 3 here >

Half of the negotiators in construction organizations (45 out of the 90 respondents) were found to be Entitleds, those known as takers at the negotiating table, which may perhaps be a root 
cause of the adversarial and non-cooperative nature of the construction industry. The majority of the respondents work for consultancy firms and thus contractually represent the client. The general aim of negotiators of such organizations is to maximize client profit in construction projects, and therefore their first priority is the client's interests. Entitled negotiators will try to employ commercial strategies to fight for the interests of their clients at the negotiating table. Interestingly, a number of Benevolents were found among the negotiators employed by contractors, which may reflect the high turnover rate of construction projects. These negotiators might have little motivation to advance the interests of their clients but rather prefer to reach an agreement with their negotiating partners as quickly as possible so as not to lose their baseline.

\section{The Three Equity Sensitivity Groups}

Having separated the sample into the three classes of negotiators, a series of one-way ANOVA were conducted to determine how the equity sensitivity groups differed in their perception of the adoption of PSAs. The significant ANOVA results were again followed by the use of Duncan's test to isolate the source of the differences (King et al. 1993). Tables 4 and 5 show the ANOVA and the Duncan's test results, respectively.

$<$ Table 4 here >

$<$ Table 5 here >

$\mathrm{H} 1, \mathrm{H} 2, \mathrm{H} 3$ and $\mathrm{H} 4$ predicted differences among the three types of negotiators in their 
perception of the adoption of a PSA to solve mutual problems $(F=17.273, p<0.01)$ and the accommodating $(\mathrm{F}=8.534, \mathrm{p}<0.05)$, honest $(\mathrm{F}=17.974, \mathrm{p}<0.01)$ and unbiased PSAs, respectively $(\mathrm{F}=5.790, \mathrm{p}<0.01)$. The ANOVA results are strongly significant, and the Duncan's test results identify two significantly different groups (Table 5). The perception of the adoption of a PSA to solve mutual problems differs significantly among the three types of negotiators, thus providing support for $\mathrm{H} 1$. The mean Benevolent score, 5.27 , is $26 \%$ and $64 \%$ greater than the Equity Sensitive and Entitled scores of 4.17 and 3.21, respectively. This result is unsurprising, given the inherent traits of benevolent negotiators, and provides statistical support for the proposition of Mintu-Wimsatt (2005) and King et al. (1993) that this type of negotiator has a propensity to solve mutual problems during the negotiation process. This result also serves as evidence that this proposition is applicable to the construction industry, even though it is characterized by a confrontational culture (CIRC 2001; Egan 1998). Benevolent negotiators are more likely to create an environment that fosters cooperation and teamwork, which can obviously lead to the achievement of mutually beneficial outcomes. No significant differences were found between entitled and equity-sensitive negotiators in their perceptions of the adoption of an accommodating PSA, but benevolent negotiators were significantly different from both, which provides partial support for H2. According to the well-known and accepted dual-concern model (Thomas, 1976), the accommodating approach is characterized by a low degree of concern for oneself and a high degree of concern for others, which, to a certain extent, is consistent with the behavioral traits of the benevolent negotiator, 
who is known as the giver at the negotiating table. It is thus expected that these negotiators will tend to adopt an accommodating PSA more frequently than either their equity-sensitive or entitled counterparts.

The results of Duncan's test also reveal that benevolent negotiators are significantly different from the other two types in their perception of the adoption of honest and unbiased PSAs. The cell means presented in Table 5 show that benevolent negotiators have a significantly greater preference for these two types of strategies. Table 5 also shows that the scores obtained for the extent of adoption of an honest PSA remain above the median of the 7-point scale across the three classes of negotiators, which indicates the general practice of honesty in negotiation in the construction industry. These negotiations are regulated by contracts that define the obligations and rights of the contracting parties (Cheung et al. 2008), and deceptive strategies, such as hiding information, shaping impressions or making false statements (Provis 2000), are seen as impeding effective negotiation. Most importantly, a dishonest approach could lead to the tarnishing of reputations and ongoing business relationships, which would restrict future tender opportunities.

With regard to the level of negotiation satisfaction, H5 and H6 are partially supported. The ANOVA results presented in Table 6 show significant differences in the level of satisfaction with negotiation outcomes $(\mathrm{F}=4.006, \mathrm{p}<0.05)$ and satisfaction with negotiation outcomes relative to pre-negotiation expectations $(\mathrm{F}=5.049, \mathrm{p}<0.05)$ among the three classes of negotiators $(\mathrm{F}=4.006, \mathrm{p}<0.05)$. The results of Duncan's test show that entitled negotiators 
are significantly different from their equity-sensitive and benevolent counterparts, but no significant differences are found between the latter two. Benevolent and equity-sensitive negotiators thus have a significantly higher level of negotiation satisfaction than do entitled negotiators, which is consistent with the research findings of Huseman et al. (1985), King et al. (1993) and Graham (1994). According to these studies, the higher level of satisfaction among Benevolents and Equity Sensitives is the result of the adoption of PSAs in the course of negotiation. Finally, $\mathrm{H} 7$ and $\mathrm{H} 8$ are not supported, as no significant differences are found among the three classes of negotiators in terms of the level of their satisfaction with their organizational profit level and performance at the negotiating table. Table 7 shows that the cell means for these two items remain above the median on the 7-point scale, which implies that all three types of negotiators have achieved satisfaction in these two respects.

\author{
$<$ Table 6 here > \\ $<$ Table 7 here >
}

\title{
Application of the Results
}

Understanding the relationship between equity sensitivity and perception of the adoption of a PSA can significantly benefit negotiators of construction organizations, including project managers, engineers and surveyors, as the results of this study suggest the latter depends on the former to a certain extent. This finding is particularly relevant to the corporate managers of construction firms because it suggests that their negotiators can be differentiated by their perception of the adoption of a PSA. 
Creating the right match between a negotiator's inherent equity sensitivity traits and the negotiation agenda would enhance the effectiveness of the negotiation process. This study provides insight to elaborate this proposition, and suggests the following guidelines for corporate managers of construction organizations in choosing negotiators.

(1) This study revealed that benevolent negotiators are more likely to want to solve mutual problems. They are instrumental in creating a cooperative environment and fostering team spirit. Corporate managers should make use of these strengths of the benevolent negotiator to sustain long-term business relationship with their partners, which is particularly important in the current harsh economic environment. Sustaining a competitive advantage and preserving good client-contractor relationships are crucial to construction organizations.

(2) This study showed that entitled negotiators have relatively lower levels of negotiation satisfaction compared to their benevolent and equity-sensitive counterparts. Corporate managers should be aware of the implication of sending entitled negotiators to the negotiating table if their aim is to repair a relationship with negotiating partners and solicit their cooperation.

(3) Corporate managers should also be aware of the questionable effectiveness of assigning benevolent negotiators to promote corporate interests. This type of negotiator is regarded as a giver at the negotiating table, and tends to adopt an accommodating PSA more frequently than do the other types. 
The results of this study also suggest possible research directions. As a PSA can incorporate many elements of cooperative behavior, we strongly recommend that future researchers adopt this study as a starting point to investigate different types of cooperative behavior among construction negotiators. For instance, of interest to both construction practitioners and academics is understanding the negotiation strategies or tactics used by negotiators to enhance cooperation, and their willingness to make concessions at the negotiating table.

Given the current global financial crisis, construction demand has been shrinking; consequently, construction firms are experiencing financial difficulties. They are becoming more claim-conscious and driving harder bargains, and construction practitioners are finding it harder to negotiate disputes that arise. Future researchers should examine the effectiveness of adopting a PSA in such situations.

\section{Study Limitations}

This study has two possible limitations that stem from (1) the method of data collection and (2) the possibility of retrospective error among the respondents, both of which have been noted previously by Yiu et al. (2008). In this study, the data on equity sensitivity, perception of the adoption of a PSA and level of negotiation satisfaction were obtained from a self-report questionnaire that asked about a recently completed negotiation case. The reliability of self-reported negotiation behavior and the accuracy of the memory of respondents are often key concerns on the part of journal reviewers. Negotiations are not often highly publicized in 
the workplace, which is one of the practical limitations of recording longitudinal data on negotiation in the construction industry. The authors have therefore taken a major precaution, which they have reported previously (Yiu et al. 2008). To ensure greater data reliability, the sample comprised highly qualified construction organizations that included government agencies, developers, consultancy firms and contractors. Approximately half (48\%) of the respondents had at least 10 years of experience in construction negotiation. The effect of retrospective error should thus be less than that found in non-construction-related negotiation research carried out using samples of undergraduate or postgraduate students.

\section{Conclusions}

The adoption of a problem-solving approach (PSA) is one of the most effective ways of mitigating the typically adversarial and non-cooperative nature of negotiations in the construction industry. Previous research strongly suggests that the adoption of a PSA by one negotiating party will trigger reciprocal behavior among the negotiating partners, prompting them to use a similar approach. In construction, however, negotiators are often faced with a tough negotiation process that involves diverse interests among the contracting parties. This situation may pose particular difficulties for negotiators who would like to adopt an equitable PSA. To find a way to overcome these difficulties, this study applies equity sensitivity theory to examine how a negotiator's sensitivity to perceived equity or inequity varies with his or her perception of the adoption of a PSA in construction negotiations. Three types of negotiators, 
benevolent (known as "givers"), equity sensitive and entitled (known as "takers"), are identified among a sample of negotiators, with the results suggesting that most negotiators are the entitled type. Benevolent negotiators are found to have a significantly greater preference for the adoption of PSAs compared to the other types of negotiators. The findings of this study are particularly relevant to the corporate managers of construction organizations, as they suggest that the right match between a negotiator's inherent equity sensitivity traits and the negotiation agenda can enhance the effectiveness of the negotiating process.

\section{Acknowledgement}

The authors would like to thank the editor and anonymous reviewers for their comments and suggestions. The work described in this paper was fully supported by a grant from the City University of Hong Kong (Project No. 7002301). 


\section{References}

1. Adams, J. (1963). Towards an understanding of inequity. Journal of Abnormal and Social Psychology, 67, 422-436.

2. Adams, J. (1965). Inequity in social exchange. Advances in Experimental Social Psychology (Vol. 2). New York: Academic Press.

3. Adler, N. J. and Graham, John L. (1989). Cross-cultural interaction: The international comparison fallacy. Journal of International Business Studies, 515-537.

4. Alexander, J. F., Schul, P. L. and Bakaus, E. (1991). Analyzing interpersonal communications in industrial marketing negotiations. Journal of the Academy of Marketing Science, 19, 129-139.

5. Allen, R. S. and White, C. S. (2002). Equity sensitivity theory: A test of responses to two types of under-reward situations. Journal of Managerial Issues, 14(4), 435-451.

6. Allen, R. S., Takeda, M. and White, C. S. (2005). Cross-cultural equity sensitivity: A test of differences between the United States and Japan. Journal of Managerial Psychology, 20(8), 641-662.

7. Al-Momani, A. H. (2000). Construction delay: A quantitative analysis. International Journal of Project Management, 18(1), 51-59.

8. Bing, M. N. and Burroughs, S. M. (2001). The predictive and interactive effects of equity sensitivity in teamwork-oriented organizations. Journal of Organizational Behavior, 22(3), 271-290. 
9. Blakely, G. L., Andrews, M. C. and Moorman, R. H. (2005). The moderating effects of equity sensitivity on the relationship between organizational justice and organizational citizenship behaviors. Journal of Business and Psychology, 20(2), 259-273.

10. Calantone, R. J., Graham, J. L. and Mintu-Wimsatt, A. (1998). Problem-solving approach in an international context: Antecedents and outcome. International Journal of Research in Marketing, 19-35.

11. Campbell, N., Graham, J., Jolibert, A. and Meissner, H. G. (1988). Marketing negotiations in France, Germany, the United Kingdom, and the United States. Journal of Marketing, 52, 46-62.

12. Cheung, S. O. and Liu, A. (1995). Settling construction disputes: A Hong Kong Perspective. Proceedings of the CIB Conference, TG15, Tokyo, 173-183.

13. Cheung, S. O., Ng, T. S. T., Wong, S. P. and Suen, H. C. H. (2003). Behavioral aspects in construction partnering. International Journal of Project Management, 21(5), 333-343.

14. Cheung, S. O., Suen, H. C. H. and Lam, P. (2002). The fundamentals of ADR processes in construction. Construction Engineering and Management, 128(5), 409-417.

15. Cheung, S. O., Wong, W. K., Yiu, T. W. and Kwok, T.W. (2008). Exploring the influence of contract governance on construction dispute negotiation. Journal of Professional Issues in Engineering Education and Practice, 134(4), 391-398.

16. Construction Industry Review Committee, CIRC (2001). Tang's report on the Hong Kong Construction Industry Reform. 
17. Dabholkar, P., Johnston, W. and Cathey, A. (1994). The dynamics of long-term business-to-business exchange relationships. Journal of the Academy of Marketing Science, 22, 130-145.

18. Egan, J. (1998). Rethinking construction. Department of the Environment, Transport and the Regions, HMSO, London.

19. Eliashberg, J., Lilien, G. and Kim, N. (1995). Searching for generalizations in business marketing negotiation. Marketing Science, 14, G47-G60.

20. Foote, D. A. and Harmon, S. (2006). Measuring equity sensitivity. Journal of Managerial Psychology, 21(2), 90-108.

21. Ganesan, S. (1994). Determinants of long-term orientation in buyer-seller relationships. Journal of Marketing, 58, 1-19.

22. Ghuari, P. (1986). Guidelines for international marketing negotiations. International Marketing Review, 72-81.

23. Goering, E. (1997). Integration versus distribution in contract negotiations: An interaction analysis of strategy use. Journal of Business Communication, 34, 383-400.

24. Graham, J. (1985). Cross-cultural marketing negotiations: A laboratory experiment. Marketing Science, 4, 130-146.

25. Graham, J. (1986). The problem-solving approach to negotiations in industrial marketing. J. Business Res., 14, 549-566.

26. Graham, J. L. and Andrews, D. (1987). A holistic analysis of cross-cultural business 
negotiations. Journal of Business Communication, 24(4), 63-77.

27. Graham, J., Mintu, A. and Rodgers, W. (1994). Explorations of negotiation behaviors in ten foreign cultures using a model developed in the United States. Management Science, 40, 72-95.

28. Huseman, R., Hatfield, J. and Miles, E. (1987). A new perspective on equity theory: The equity sensitivity construct. Academy of Management Review, 12, 222-234.

29. Huseman, R. C., Hatfield, J. D. and Miles, E. W. (1985). Test for individual perceptions of job equity: Some preliminary findings. Perceptual and Motor Skills, 61, 1055-1064.

30. Nickerson, J. A. and Zenger, T. R. (2004). A knowledge-based theory of the firm: The problem-solving perspective. Organization Science, 15, 617-632.

31. Jannadia, M. O., Assaf, S., Bubshait, A. A. and Naji, A. (2000). Contractual methods for dispute avoidance and resolution (DAR). International Journal of Project Management, $18,41-49$.

32. Kickul, J. and Lester, S. W. (2001). Broken promises: Equity sensitivity as a moderator between psychological contract breach and employee attitudes and behavior. Journal of Business and Psychology, 16, 191-217.

33. King, W., Miles, E. and Day, D. (1993). A test and refinement of the equity sensitivity construct. Journal of Organizational Behavior, 67, 133-142.

34. Latham, M. (1994). Constructing the team: Final report by Sir Michael Latham; Joint Review of Procurement and Contractual Arrangements in the United Kingdom 
Construction Industry. London: HMSO.

35. Loosemore, M. (1999). Bargaining tactics in construction disputes. Construction Management and Economics, 17, 177-188.

36. McLoughlin, D. and Carr, S. C. (1997). Equity sensitivity and double demotivation. Journal of Social Psychology, 137, 668-670.

37. Miles, E., Hatfield, J. and Huseman, R. (1989). The equity sensitivity construct: Potential implications for worker performance. Journal of Management, 15, 581-588.

38. Miles, E., Hatfield, J. and Huseman, R. (1994). Equity sensitivity and outcome importance. Journal of Organizational Behavior, 15, 585-596.

39. Mintu-Wimsatt, A. (2003). King and Miles' equity sensitivity instrument: A cross-cultural validation. Psychological Reports, 92, 23-26.

40. Mintu-Wimsatt, A. (2005). Equity sensitivity and negotiation behaviors: A look at Mexican exporters. Academy of Marketing Science Review [online].

41. Mintu-Wimsatt, A. and Graham, J. (2004). Testing a negotiation model on Canadian anglophone and Mexican exporters. Journal of the Academy of Marketing Science, 32(3), 345-356.

42. Montgomery, D. (1996). Design and analysis of experiments ( $4^{\text {th }}$ edition). New York : Wiley.

43. Mosak, H. H. (1959). The getting type: A parsimonious social interpretation of moral character. Journal of Individual Psychology, 15, 193-198. 
44. O’Neil, B. S. and Mone, M. A. (1998). Investigating equity sensitivity as a moderator of relations between self-efficacy and workplace attitudes. Journal of Applied Psychology, 83(5), 805-816.

45. Patrick, S. and Jackson, J. (1991). Further examination of the equity sensitivity construct. Perceptual Motor Skills, 73, 1091-1106.

46. Pinnell, S. (1999). Partnering and the management of construction disputes. Dispute Resolution Journal, 54(1), 16-22.

47. Provis, C. (2000). Honesty in negotiation. Business Ethics: A European Review, 9(1), $3-12$.

48. Putnam, L. L. and Jones, T. S. (1982). Reciprocity in negotiations: An analysis of bargaining interaction. Communication Monographs, 49, 171-191.

49. Rahim, M.A. (2002). Toward a theory of managing organizational conflict. International Journal of Conflict Management, 13(3), 206-235.

50. Ruyter, K. and Wetzels, M. (2000). Customer equity considerations in service recovery: A cross industry perspective. International Journal of Service Industry Management, 11(1), 91-108.

51. Rychlak, J. F. (1973). Introduction to personality and psychotherapy. Boston: Houghton Mifflin.

52. Sauley, K. S. and Bedeian, A. G. (2000). Equity sensitivity: Construction of a measure and examination of its psychometric properties. Journal of Management, 26(5), 885-910. 
53. Scott, B. A. and Colquitt, J. A. (2007). Are organizational justice effects bounded by individual differences? An examination of equity sensitivity, exchange ideology and the big five. Group and Organizational Management, 32(3), 290-325.

54. Shore, T. H. (2004). Equity sensitivity theory: Do we all want more than we deserve? Journal of Managerial Psychology, 19(7), 722-728.

55. Steen, R. H. and MacPherson, R. J. (2000). Resolving construction disputes out of court through ADR. Journal of Property Management, 65(5), 58-60.

56. Thomas, K. W. (1976). Conflict and conflict management. In M. D. Dunnette (Ed.), Handbook of industrial and organizational psychology. Chicago: Rand McNally.

57. Thompson, B. (2006). Foundations of behavioral statistics. New York: Guilford.

58. Tornow, W. M. (1971). The development and application of an input-outcome moderator test on the perception and reduction of inequity. Organizational Behavior and Human Performance, 6, 614-638.

59. Wheeler, K. G. (2002). Cultural values in relation to equity sensitivity within and across Cultures. Journal of Managerial Psychology, September/October, 612-627.

60. Yiu, T. W. and Cheung, S. O. (2006). Are construction disputes inevitable? IEEE Transactions on Engineering Management, 53(3), 456-470.

61. Yiu, T. W., Cheung, S. O. and Chow, P. T. (2008). Logistic regression modeling of construction negotiation outcomes. IEEE Transactions on Engineering Management, $55(3), 468-478$. 
62. Zack, J. G. (1995). Practical dispute management. Cost Engineering, 37(12), 55. 
Appendix A: Equity Sensitivity Instrument (ESI) for Negotiation among Construction Organizations (modified from Mintu-Wimsatt [2005])

For each question, divide 10 points between the two choices (Choices $\mathrm{A}$ and $\mathrm{B}$ ):

During a negotiation process:

1. It would be more important for me to:
A. Get something for nothing

B. Give something

2. It would be more important for me to:

A. Help my counterparts if they needed help

B. Look out for my own negotiation outcomes

3. I would be more concerned about:

A. What I received from the negotiation

B. What I contributed to the negotiation

4. The hard work I do should:

A. Benefit the entire negotiation process

B. Benefit my negotiation outcomes

5 My personal philosophy in dealing with the negotiation is:

A. If I do not look out for myself, then nobody else will

B. It is better for me to give than to receive

Appendix B: Problem Solving Approach (PSA) Dimensions (modified from Graham [1986])

(1) If a negotiation outcome(s) was reached, how satisfied were you with the resulting agreement?

(2) How satisfied were you with the negotiation outcome(s) relative to your pre-negotiation expectations?

(3) How satisfied were you with your organizational profit level?

(4) How satisfied were you with your performance during the negotiation?

(5) Do you feel that you are more interested in solving mutual problems or are more self-interested? ${ }^{\text {ii }}$

(6) Rate the respondent's bargaining strategies on the following scale:

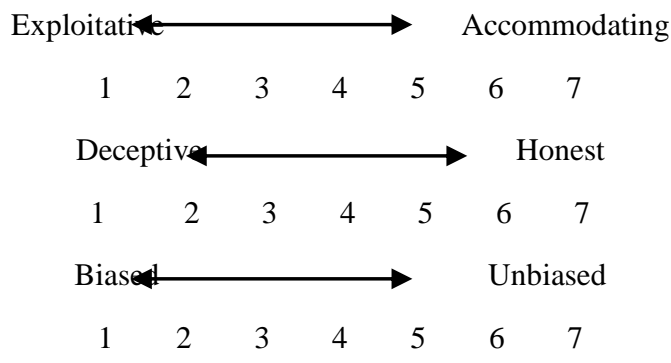

${ }^{i}$ Respondents were rated on a 7-point Likert scale that ranged from 1 for a low degree of satisfaction to 7 for a high degree of satisfaction.

ii Respondents were rated on a 7-point Likert scale that ranged from 1 for self-interested to 7 for interested in solving mutual problems. 
Table 1. Composition of respondents by organization type

\begin{tabular}{llccc}
\hline Type of Organization & $\begin{array}{c}\text { Sent } \\
\text { (Nos.) }\end{array}$ & $\begin{array}{c}\text { Returned } \\
\text { (Nos.) }\end{array}$ & $\begin{array}{c}\text { Response Rate } \\
(\%)\end{array}$ \\
\hline a. & Private Developer & 20 & 8 & 40.0 \\
b. Government Agency & 20 & 15 & 75.0 \\
c. Consultancy Firm & 80 & 40 & 50.0 \\
d. Contractor & 45 & 27 & 60.0 \\
\hline & TOTAL & 165 & 90 & 54.5 \\
\hline
\end{tabular}


Table 2. Breakpoints of the ESI scores (Huseman et al. 1985; Miles et al. 1989)

\begin{tabular}{lc}
\hline Three Classes of Negotiators & Breakpoints of ESI Scores \\
\hline Entitleds & $0-20$ \\
Equity Sensitives & $21-27$ \\
Benevolents & $28-50$ \\
\hline
\end{tabular}


Table 3. The three classes of negotiators (by organization type)

\begin{tabular}{|c|c|c|c|}
\hline & \multicolumn{3}{|c|}{ Three Classes of Negotiators } \\
\hline & Entitleds & Equity Sensitives & Benevolents \\
\hline Private Developer & 5 & 3 & 0 \\
\hline Government Agency & 8 & 6 & 1 \\
\hline Consultancy Firm & 18 & 13 & 9 \\
\hline Contractor & 14 & 3 & 10 \\
\hline Total & 45 & 25 & 20 \\
\hline
\end{tabular}


Table 4. Results of one-way ANOVA

\begin{tabular}{|c|c|c|c|c|c|c|}
\hline & & & SS* & df & $\mathbf{F}$ & Sig. \\
\hline \multirow{12}{*}{ 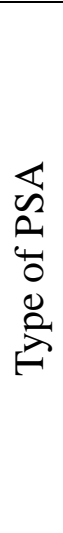 } & \multirow{3}{*}{ Solving Mutual Problems } & Between Groups & 58.31 & 2 & 17.273 & $.000 * *$ \\
\hline & & Within Groups & 146.85 & 87 & & \\
\hline & & Total & 205.16 & 89 & & \\
\hline & \multirow{3}{*}{ Accommodating } & Between Groups & 22.85 & 2 & 8.534 & $.000 * *$ \\
\hline & & Within Groups & 116.44 & 87 & & \\
\hline & & Total & 139.29 & 89 & & \\
\hline & \multirow[t]{3}{*}{ Honest } & Between Groups & 48.24 & 2 & 17.974 & $.000 * *$ \\
\hline & & Within Groups & 116.75 & 87 & & \\
\hline & & Total & 164.99 & 89 & & \\
\hline & \multirow{3}{*}{ Unbiased } & Between Groups & 19.31 & 2 & 5.790 & $.004 * *$ \\
\hline & & Within Groups & 145.09 & 87 & & \\
\hline & & Total & 164.40 & 89 & & \\
\hline
\end{tabular}


Table 5. Results of Duncan's Multiple Range Test

\begin{tabular}{lcccc}
\hline & \multicolumn{3}{c}{ Cell Means } & \\
\cline { 2 - 5 } & ENT(n= 29) & EQS(n= 35) & $\begin{array}{l}\text { BEN(n = } \\
\text { Duncan's Test* }\end{array}$ \\
\hline Solving Mutual & 3.21 & 4.17 & 5.27 & ENT EQS BEN \\
Problems & 3.76 & 4.23 & 5.04 & ENT EQS BEN \\
\hline Accommodating & 4.34 & 4.69 & 6.12 & ENT EQS BEN \\
\hline Honest & 3.93 & 4.43 & 5.12 & ENT EQS BEN \\
\hline Unbiased & & & & \\
\hline $\begin{array}{l}\text { BEN: Benevolent negotiator; EQS: Equity-sensitive negotiator; ENT: Entitled negotiator. } \\
\text { *Groups connected by a solid line are not significantly different from one another. }\end{array}$ \\
\hline
\end{tabular}


Table 6. Results of one-way ANOVA

\begin{tabular}{|c|c|c|c|c|c|}
\hline & & SS & df & $\mathbf{F}$ & Sig. \\
\hline \multirow{3}{*}{$\begin{array}{l}\text { Satisfaction with } \\
\text { negotiation outcomes }\end{array}$} & Between Groups & 6.011 & 2 & 4.006 & $.022 *$ \\
\hline & Within Groups & 65.278 & 87 & & \\
\hline & Total & 71.289 & 89 & & \\
\hline \multirow{3}{*}{$\begin{array}{l}\text { Satisfaction relative to } \\
\text { pre-negotiation } \\
\text { expectations }\end{array}$} & Between Groups & 12.209 & 2 & 5.049 & $.008 * *$ \\
\hline & Within Groups & 105.180 & 87 & & \\
\hline & Total & 117.389 & 89 & & \\
\hline \multirow{3}{*}{$\begin{array}{l}\text { Satisfaction with } \\
\text { organizational profit level }\end{array}$} & Between Groups & 7.273 & 2 & 2.569 & .082 \\
\hline & Within Groups & 123.182 & 87 & & \\
\hline & Total & 130.456 & 89 & & \\
\hline \multirow{3}{*}{$\begin{array}{l}\text { Satisfaction with } \\
\text { negotiating performance }\end{array}$} & Between Groups & 1.065 & 2 & .522 & .595 \\
\hline & Within Groups & 88.724 & 87 & & \\
\hline & Total & 89.789 & 89 & & \\
\hline
\end{tabular}


Table 7. Duncan's Multiple Range Test results on negotiation satisfaction

\begin{tabular}{lcccc}
\hline & \multicolumn{3}{c}{ Cell Means } & \\
\cline { 2 - 4 } & ENT(n = 29) & EQS(n= 35) & BEN(n = 26) & Duncan's Test* \\
\hline $\begin{array}{l}\text { Satisfaction with } \\
\text { negotiation outcomes }\end{array}$ & 4.72 & 5.20 & 5.35 & ENT EQS BEN \\
\hline $\begin{array}{l}\text { Satisfaction relative to } \\
\text { pre-negotiation } \\
\text { expectations }\end{array}$ & 4.14 & 4.66 & 5.08 & ENT EQS BEN \\
\hline $\begin{array}{l}\text { Satisfaction with } \\
\text { organizational profit } \\
\text { level }\end{array}$ & 4.28 & 4.31 & 4.92 & ENT EQS BEN \\
\hline $\begin{array}{l}\text { Satisfaction with } \\
\text { negotiating } \\
\text { performance }\end{array}$ & 4.97 & 4.47 & 4.77 & ENT EQS BEN \\
\hline $\begin{array}{l}\text { BEN: Benevolent negotiator; EQS: Equity-sensitive negotiator; ENT: Entitled negotiator. } \\
* \text { Groups connected by a solid line are not significantly different from one another. }\end{array}$ \\
\hline
\end{tabular}


Application of Equity Sensitivity Theory to

Problem-Solving Approaches in

Construction Dispute Negotiation

\author{
Yiu, TW
}

2011-01

http:/hdl.handle.net/10179/16595

22/04/2023 - Downloaded from MASSEY RESEARCH ONLINE 